\title{
Pengabdian Perbaikan Fasilitas Mesin Produksi Keripik Tempe di Panti Asuhan Bhakti Luhur
}

\author{
Chandra Sundaygara ${ }^{1}$, Dwi Wahyuningsih ${ }^{2}$, Kurriawan Budi Pranata ${ }^{3}$, Solikhan $^{4}$ \\ 1,2,3,4 Prodi Pendidikan Fisika, ${ }^{1,2,3,4}$ Fakultas Sains dan Teknologi, \\ 1,2,3,4 Universitas Kanjuruhan Malang \\ e-mail: ${ }^{1}$ chandrakirana@unikama.ac.id, ${ }^{3}$ kurriawan@unikama.ac.id
}

\begin{abstract}
Abstrak
Bhakti Luhur merupakan panti asuhan orang cacat tubuh, cacat bicara, dan down syndrome. Panti ini memiliki komitmen untuk meningkatkan ketrampilan berwirausaha bagi kaum disabilitas. Namun, hal itu terkendala oleh fasilitas panti asuhan yang mengandalkan donasi santunan yang bersifat sukarela. Sehingga tidak dapat dijadikan pengembangan fasilitas yang berkelanjutan. Meskipun demikian, keterbatasan fasilitas panti asuhan tidak menyurutkan semangat pengelola untuk melatih orang disabilitas menjadi wirausahawan yang mandiri. Salah satu minim fasilitas tersebut pada ketrampilan pembuatan camilan keripik tempe. Selama ini, keripik tempe di panti asuhan dibuat dengan cara tradisional. Tempe diiris tipis dengan pisau untuk menjadi keripik. Akibatnya bentuk irisan tidak homogen dan waktu produksi menjadi sangat lama. Teknologi yang ditransfer dalam kegiatan pengabdian ini yaitu pengadaan alat perajang keripik tempe menggunakan metode pengiris semi otomatis. Mesin perajang yang diterapkan bersifat portable, safety bagi penyandang disabilitas serta dapat mempersingkat waktu produksi. Melalui metode pelaksanaan kegiatan ceramah, diskusi, demplot pendampingan dan demonstrasi mesin produksi telah didapatkan hasil kegiatan pengabdian ini meliputi (1) Peningkatan fasilitas (2) Peningkatan ketrampilan berwirausaha, (3) Mempersingkat waktu produksi (4) Bertambahnya wawasan Mitra pentingnya pengelolaan proses produksi yang safety bagi penyandang disabilitas. Kesimpulan sebelum dan sesudah dari kegiatan ini yaitu, meminimalisir kecelakaan kerja. Selain itu, waktu produksi menjadi singkat, sebelumnya butuh 2 jam sekarang menjadi 30 menit.
\end{abstract}

Kata kunci: cacat tubuh; down syndrome; portable; safety

\begin{abstract}
Bhakti Luhur is an orphanage for people with disabilities, speech disabilities, and down syndrome people. This institution has a commitment to improve entrepreneurial skills for people with disabilities. However, this was hampered by facilities for orphanages that relied on voluntary donations. So that it cannot be used as a sustainable development of facilities. Even so, the limitations of orphanage facilities do not dampen the enthusiasm of managers to train people with disabilities to become independent entrepreneurs. One of the minimal facilities is the skill of making tempe chips snacks. During this time, tempe chips in orphanages were made in the traditional way. Tempe is thinly sliced with a knife to become chips. As a result the shape of the slice is not homogeneous and the production time becomes very long. The technology transferred in this service activity is the procurement of tempe chips chopper equipment using a semi-automatic slicing method. The chopper that is applied is portable, safety for people with disabilities and can shorten production time. Through the method of conducting lectures, discussions, assistance and demonstration machine production demonstration plots, the results of this service activity have been obtained (1) Improving facilities (2) Increasing entrepreneurial skills (3) Shortening production time (4) Increasing insight into Partners' importance in managing safety production processes for persons with disabilities. he conclusion before and after this activity is to minimize work accidents. In addition, the production time is short, before it took 2 hours now to be 30 minutes
\end{abstract}

Keywords : dissability; down syndrome; portable; safety 


\section{PENDAHULUAN}

Kota Malang tidak lepas dari permasalahan sosial yang semakin buruk kualitasnya. Pemerintah Kota Malang melalui Dinas Sosial mencatat ada 50 panti asuhan [1], dan 494 difabel usia produktif berada di Kota Malang pada tahun 2017 [2], jumlah tersebut terus bertambah karena pencatatan jumlah difabel belum selesai.

Jumlah mereka yang diperkirakan bertambah itu, Dinas Sosial menyediakan program pengembangan Usaha Kesejahteraan Sosial (UKS) dengan upaya menghadirkan kemandirian ekonomi pada difabel. Pelatihan yang diberikan oleh Dinas Sosial biasanya hanya bersifat keterampilan saja, tanpa adanya tindak lanjut seperti pendampingan proses produksi, penjaminan mutu dan bagaimana manajemen pemasaran. Padahal kualitas hasil produk dan manajemen pemasaran juga ikut menentukan bagaimana para difabel bisa bersaing dan bertahan di dunia kerja. Kerap kali para penyandang disabilitas sering mendapatkan perilaku diskriminasi dari masyarakat secara umum yang sering meragukan hasil produk home industri mereka.

Masyarakat umum dan sarana prasarana yang tersedia banyak yang belum memihak para disabilitas. Sehingga penyandang disabilitas perlu menumbuhkan kemandirian secara sosial ekonomi demi meningkatkan taraf kesejahteraan. Penyandang disabilitas masih membutuhkan dorongan, bimbingan, pendampingan untuk meningkatkan pendapatan dan percayadiri mereka.

Menurut Perda Kota Malang No 2 Tahun 2014, salah satu wujud perlindungan dan pemberdayaan penyandang disabilitas adalah penyediaan akses, sarana prasarana yang memadai serta berkesinambunag dengan melibatkan peran aktif masyarakat [3]. Sejalan dengan perda tersebut, pemerintah Kota Malang juga berupaya mewujudkan kota yang memiliki banyak industri kreatif dan macam-macam home industri yang berwawasan global. Disinilah peluang penting bagi penyandang disabilitas untuk menciptakan lapangan kerja yang mandiri disaat peluang kerja semakin banyak menuntut syarat kesehatan jasmani maupun rohani. Peran berwirausaha bagi para penyandang disabilitas ini selalu dipersiapkan oleh beberapa panti asuhan yang menampung kaum difabel. Namun, kurangnya sarana prasarana sentuhan teknologi menjadi kendala bagi para pengelola panti. Berawal dari kendala inilah, tim pengabdi dari UNIKAMA melakukan transfer alih teknologi mekanik sebagai fasiltator penyediaan akses sarana prasarana yang memadai bagi kaum disabilitas.

\section{SUMBER INSPIRASI}

Bhakti luhur merupakan salah satu panti asuhan yang terbesar di Kota Malang untuk menampung kaum difabel mulai dari cacat tubuh, cacat bicara, dan down syndrome. Panti Asuhan Bhakti Luhur berkantor pusat di Jalan Dieng No. 40. Panti asuhan tersebut terdiri dari berbagai unit penampungan kaum difabel yang tersebar di daerah sekitar kota Malang. Salah satu unit yang menaungi pembelajaran berwirausaha bagi kaum difabel berada di Jl. Seruni No. 8, Lowokwaru, Kec. Lowokwaru Kota Malang.

Namun, unit pembelajaran berwirausaha yang berada di Jl. Seruni No. 8, Lowokwaru terkendala fasilitas media pembelajaran berwirausaha. Salah satu media tersebut adalah pembuatan camilan keripik tempe.

Mengacu konsistensi Perda Kota Malang No 2 Tahun 2014, salah satu wujud perlindungan dan pemberdayaan penyandang disabilitas adalah penyediaan akses, sarana prasarana yang memadai serta berkesinambunag dengan melibatkan peran aktif masyarakat [3] Kata-kata peran aktif masyarakat inilah yang menjadi sumber inspirasi kami yang berprofesi sebagai pelaku utama kegiatan Tri Dharma Perguruan Tinggi, untuk tergerak melakukan kegiatan pengabdian yang fokus pada kaum disabilitas. Kami tim pengabdi dari UNIKAMA berkomitmen untuk tergerak sebagai fasilitator transfer alih ilmu teknologi mekanik pada bagian permasalahan proses produksi pembuatan keripik tempe. Sebelum adanya kegiatan pengabdian ini 
$\underline{\text { Pengabdian Perbaikan Fasilitas Mesin Produksi Keripik Tempe di Panti Asuhan Bhakti Luhur }}$

proses produksi pengirisan keripik tempe di Panti Asuhan Bhakti Luhur masih jauh dari sentuhan teknologi. Pengirisan tempe menjadi bahan bentuk keripik masih menggunakan pisau, sehingga produk yang dihasilkan menjadi tidak seragam, waktu proses produksi menjadi sangat lama, dan tidak memperhatikan keselamatan kerja bagi kaum disabilitas. Sehingga pembelajaran berwirausaha ini hanya sebatas pemberdayaan yang bersifat pemberian kesibukan seadanya tanpa ada proses pembentukan wirausaha yang matang dan mandiri.

Adapun hasil produk olahan camilan keripik tempe hanya dijual disekitar asrama panti dan dijual disaat ada acara kebaktian gereja. Para konsumen camilan keripik tempe bhakti luhur sudah memaklumi meskipun produk keripik tersebut masih sangat jauh dari standart pasar pada umumnya. Karena para konsumen masih menganggap jika membeli keripik tempe bhakti luhur sama dengan membantu atau berdonasi dengan sifat sukarela. Jika hal ini tetap dibiarkan, keberlanjutan pemberdayaan keripik tempe di Bhakti Luhur tidak dapat berkembang dan dilibatkan dalam sektor industri wisata kuliner kota Malang. Sehingga lulusan panti asuhan Bhakti Luhur menjadi kurang terampil dalam manajemen berwirausaha jika pemasaran produk hanya sebatas disekitar asrama panti. Beberapa kendala yang dialami para perajin keripik tempe para penyandang disabilitas di Panti Asuhan Bhakti Luhur menjadi penyebab bahwa mereka membutuhkan pelatihan dan pendampingan mengenai mencacah keripik tempe, keseragaman produk cacahan, teknologi pengemasan dan pencacahan yang aman.

Pada kegiatan pengabdian yang sudah dilakukan sebelumnya yaitu oleh Kurriawan dan Annisa, salah satu unsur meminimalisir kecelakaan kerja pada sistem mesin perajang keripik terletak pada pelindung tangan saat dilakukan proses perajangan [4,5]. Sehingga teknologi yang ditransfer kepada perajin keripik tempe penyandang disabilitas berupa perbaikan tata nilai pemahaman tentang keselamatan keselamatan kerja saat melakukan proses perajangan keripik tempe. Karena selama ini, siswa disabilitas panti asuhan Bhakti Luhur mengiris tempe menjadi bentuk keripik hanya menggunakan pisau dapur. Sehingga, pemahaman dan kesadaran system keselamatan kerja sangat kurang diperhatikan.

Selain itu, perbaikan tata nilai produk juga diperhatikan yaitu berupa peningkatan bentuk produk yang homogen, peningkatan kualitas dan kuantitas produk, sedangkan perbaikan proses pengemasan produk melalui fasilitas alat pengemas hand sealer.

\section{METODE KEGIATAN}

Metode kegiatan dalam menyelsaikan berbagai masalah yang dihadapi kelompok usaha camilan penyandang disabilitas di Panti asuhan Bhakti Luhur yaitu melalui peningkatkan fasilitas, peningkatan ketrampilan berwirausaha, percepatan waktu produksi, peningkatkan wawasan pentingnya pengelolaan proses produksi yang safety bagi penyandang disabilitas. Prosedur yang digunakan dalam menyelesaikan masalah yang dihadapi Mitra penyandang disabilitas antara lain: 1) Melakukan koordinasi internal tim pengabdi dan melakukan kegiatan data sharing dengan mitra, 2) Melakukan kegiatan survey teknologi mekanik mengenai kebutuhan alat produksi pencacah keripik tempe yang safety bagi pengguna penyandang disabilitas, 3) Memberikan informasi dan pembagian tugas keterlibatan pihak mitra dalam teknis pelaksanaan kegiatan pengabdian masyarakat, 4) Melakukan pelatihan dan demonstrasi penggunaan alat perajang keripik tempe, 5) Melakukan serah terima alat produksi perajang keripik tempe kepada pihak pengelola panti asuhan Bhakti Luhur, 6) Melakukan evaluasi kegiatan pengabdian masyarakat yang dilakukan demi pemantauan keberlanjutan program, dan 7) Melakukan kerangka monitoring dan pendampingan yang berkelanjutan kepada mitra mengenai efektifitas keberfungsian alat produksi selama digunakan oleh mitra. 


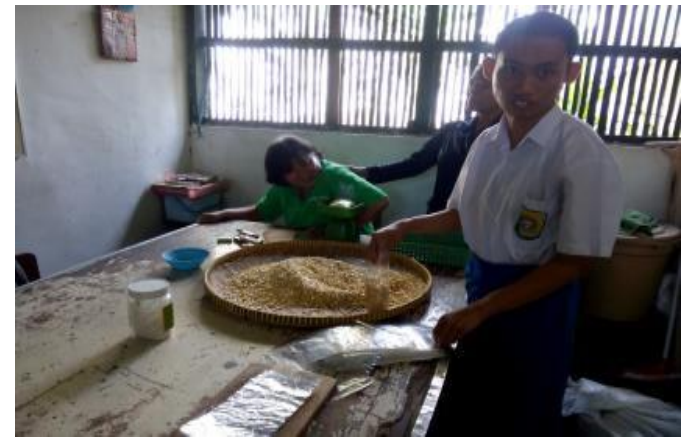

Gambar 1. Analisis data sharing fasilitas alat produksi di lokasi pembelajaran pembuatan keripik Tempe di Panti Asuhan Bhakti Luhur

Gambar 1 menunjukkan minimnya fasilitas panti asuhan Bhakti Luhur dalam pemberdayaan anak- anak penyandang disabilitas. Minimnya fasilitas proses produksi tersebut terletak pada pengelolaan dan pembuatan keripik tempe yang jauh dari sentuhan teknologi. Sehingga dapat dipastikan pembelajaran berwirausaha ini hanya bersifat pemberian kesibukan seadanya tanpa ada proses pembentukan wirausaha yang matang dan mandiri. Jika hal ini diabaikan, alumni siswa panti asuhan Bhakti Luhur menjadi kurang mandiri jika pada nantinya lulus dari panti karena minimnya ketrampilan pengelolaan proses produksi.

Hasil kegiatan observasi, telah didapatkan kelemahan pada bagian sistem rajang yang masih manual. Setelah dari kegiatan tersebut, kami lakukan diskusi diiringi dengan kegiatan survey pengadaan alat perajang yang bersifat portable, aman dan mudah penggunaanya bagi penyandang disabilitas. Telah didapatkan alat perajang keripik tempe dengan spesifikasi sebagai berikut mesin dengan daya 120 watt, diameter pisau rajang $220 \mathrm{~mm}$ dengan kapasitas mesin mampu mengiris tempe sebanyak $65 \mathrm{Kg}$ dalam satu jam, sedangkan rentang ketebalan irisan mulai daro 0-15 mm, dimensi mesin dapat dikatakan cukup portable dengan dimensi $45 \mathrm{~cm} \times 28 \mathrm{~cm} \times 32 \mathrm{~cm}$, berat mesin total 13,2 Kg. Selanjutnya alat produksi ini dikirim menggunakan mobil box tertutup menuju lokasi Mitra dan diterima lansung oleh ketua yayasan panti asuhan Bhakti Luhur yaitu berupa alat pencacah keripik tempe dan handsealer yang ditunjukkan pada Gambar 2 (a).

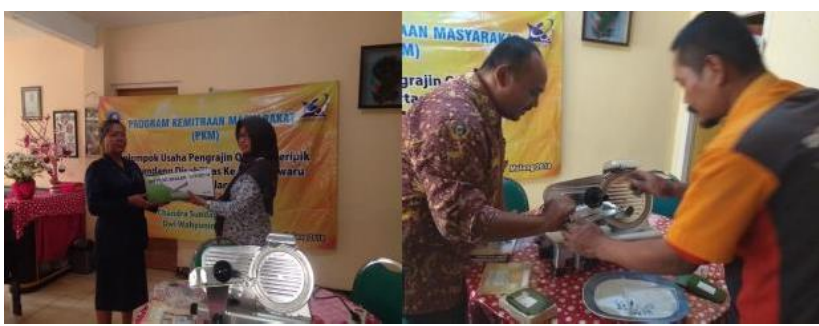

Gambar 2. (a) Serah terima alat produksi pencacah keripik tempe kepada ketua yayasan Panti asuhan Bhakti Luhur (b) Demonstrasi penggunaan alat produksi perajang keripik tempe yang didampingi oleh tim instruktur mekani

Gambar 2 (a) alat produksi pencacah keripik tempe dan handselaer telah diserah terimakan dari ketua tim pengabdi kepada ketua yayasan Panti Asuhan Bhakti Luhur oleh Ibu Marcel. Selain itu, dilanjutkan dengan metode pelaksanaan kegiatan pelatihan dan demonstrasi seperti yang dilakukan pada Muhammad Priyono [6]. Pelatihan dan demonstrasi alat perajang tersebut telah dipandu oleh anggota tim pengabdi dan didampingi oleh instruktur mekanik. Adapun demonstrasi tersebut dihadiri beberapa siswa panti dan suster perawat panti asuhan Bhakti Luhur yang dilakukan selama satu hari penuh. Mekanisme demonstrasi telah diuraikan menjadi beberapa tahapan yang mengacu pada prosedur tahapan kegiatan yang dilakukan oleh Azimatul yaitu [7]. 1) Sebelum dilakukan demonstrasi, para peserta pengadian masyarakat diberikan materi penjelasan tentang manual prosedur penggunaan mesin perajang keripik, 2) 10 peserta diminta mengerjakan soal pre-test dengan soal uraian guna mengetahui pola kinerja ilmiah dari peserta, 3) Dilakukan pelatihan dan demonstrasi cara kerja pengoperasian perajang keripik tempe, dan 4) Setelah pelatihan dilakukan, peserta diminta kembali mengerjakan soal post-test dan mengisi kuisioner kepuasan pelatihan. Karena peserta yang didatangkan dari panti adalah kaum difabel cacat tubuh, sehingga memberikan hasil yang sangat signifikan pada indikator pemahaman pengoperasian mesin untuk memetakan pola kinerja ilmiah. Hasil pre-test pada indikator pemahaman dengan perlakuan membaca manual prosedur menunjukkan nilai rerata 40\%. Namun, setelah dilakukan demonstrasi meningkat dengan rerata $60 \%$. 
$\underline{\text { Pengabdian Perbaikan Fasilitas Mesin Produksi Keripik Tempe di Panti Asuhan Bhakti Luhur }}$

Sedangkan faktor kepuasan dengan adanya kegiatan ini mendapatkan nilai rerata $75 \%$.

Berdasarkan beberapa tahapan kegiatan demonstrasi alat produksi perajang keripik tempe diBerdasarkan beberapa tahapan kegiatan demonstrasi alat produksi perajang keripik tempe diatas, telah didapatkan peningkatan pengetahuan sebesar 60,1\% meliputi: 1) Pemahaman pemeriksaan awal mesin sesuai prosedur dan standart kerja yang ditetapkan 55\%, 2) Pemahaman langkah-langkah awal pengoperasian mesin perajang keripik tempe $70 \%$ 3) Pemahaman pengoperasian penggunaan variasi bahan rajang dan variasi rentang dimensi ketebalan rajang 63\%,4) Pemahaman penerapan sistem safety mesin rajang keripik tempe 80\%, 5) Pemahaman prosedur bilas cuci mesin setelah digunakan $58 \%$, 6) Pemahaman maintence dan kebersihan mesin demi keberlangsungan umur mesin 50\%, dan 7) Pemahaman sistem bongkar, pasang, rakit dan cara penyimpanan bagi mesin perajang keripik tempe yang digunakan $45 \%$.

\section{KARYA UTAMA}

Pada karya hasil pengabdian masyarakat yang dilakukan ini telah memiliki beberapa keunggulan dan kelemahan meliputi: keunggulan Karya Pengabdiana Masyarakat di Panti Asuhan Bhakti Luhur meliputi bertambahnya fasilitas mesin produksi keripik tempe sebagai upaya peningkatan ketrampilan pemberdayaan wirausaha bagi penyandang disabilitas. Selain itu juga sebagai rujukan bagi para penyandang kaum disabilitas yang mempunyai tekad kuad untuk menjadi wirausahawan bidang produksi olahan camilan keripik.

Adapun kelemahan dari Karya Pengabdiana Masyarakat di Panti Asuhan Bhakti Luhur yaitu kesulitan dalam transfer alih teknologi mekanik, dimana peserta merupakan kaum disalabilitas yang membutuhkan proses pembelajaran yang khusus.

Keberlangsungan program pengabdian masyarakat bagi kaum disabilitas sangat mungkin untuk dikembangkan yaitu pembuatan/penerapan metode atau model pembelajaran yang khusus dengan mengutamakan penerapan IPTEK bagi kaum disabilitas. Sehingga dapat meningkatkan kemampuan kerja ilmiah dan pola berpikir kritis guna sebagai bekal kehidupan yang mandiri.

\section{KESIMPULAN}

Berdasarkan kegiatan pengabdian masyarakat yang sudah dilakukan didapatkan kesimpulan sebagai berikut: 1) Pengadaan fasilitas mesin produksi olahan camilan keripik tempe ternyata dapat meningkatkan ketrampilan dan hasrat yang kuat untuk berwirausaha bagi para kaum disabilitas, 2) Dengan adanya mesin produksi olahan camilan keripik tempe ternyata dapat mempersingkat waktu proses pengirisan sehingga didapatkan bentuk irisan keripik yang seragam, 3) Melalui kegiatan demonstrasi mesin produksi keripik tempe yang dilakukan, ternyata memiliki pengaruh yang signifikan terhadap pemahaman tentang keselamatan kerja, 4) Berdasarkan hasil evaluasi kegiatan, mayoritas peserta kegiatan pengabdian merasa puas dengan materi yang disampaikan dan fasilitas yang diberikan tim pengabdi, 5) Berdasarkan hasil kerangka kegiatan pemantauan keberlanjutan program, alat produksi keripik tempe memberikan efektifitas proses pembelajaran wirausawan bagi kaum disabilitas, dan 6) Saran dari hasil kegiatan pengabdian masayarakat yang sudah dilakukan ini adalah pentingnya suatu pengembangan metode atau model pembelajaran yang khusus bagi para penyandang disabilitas untuk kegiatan pengabdian selanjutnya. Model atau metode tersebut dapat berupa suatu modul, pengembangan bahan ajar, atau langkah-langkah pembelajaran yang khusus guna meningkatkan ketrampilan kerja ilmiah dan pola berpikir kritis untuk meningkatkan kemandirian belajar para kaum disabilitas.

\section{ULASAN KARYA}

Pada karya hasil pengabdian masyarakat yang dilakukan ini telah memiliki beberapa keunggulan dan kelemahan meliputi: keunggulan Karya Pengabdiana Masyarakat di Panti Asuhan Bhakti Luhur meliputi bertambahnya fasilitas mesin produksi keripik tempe sebagai upaya peningkatan ketrampilan pemberdayaan 
wirausaha bagi penyandang disabilitas. Selain itu juga sebagai rujukan bagi para penyandang kaum disabilitas yang mempunyai tekad kuad untuk menjadi wirausahawan bidang produksi olahan camilan keripik.

Adapun kelemahan dari Karya Pengabdiana Masyarakat di Panti Asuhan Bhakti Luhur yaitu kesulitan dalam transfer alih teknologi mekanik, dimana peserta merupakan kaum disalabilitas yang membutuhkan proses pembelajaran yang khusus.

Keberlangsungan program pengabdian masyarakat bagi kaum disabilitas sangat mungkin untuk dikembangkan yaitu pembuatan/penerapan metode atau model pembelajaran yang khusus dengan mengutamakan penerapan IPTEK bagi kaum disabilitas. Sehingga dapat meningkatkan kemampuan kerja ilmiah dan pola berpikir kritis guna sebagai bekal kehidupan yang mandiri.

\section{DAMPAK DAN MANFAAT KEGIATAN}

Dampak dan manfaat kegiatan pengabdian yang sudah dilakukan mengacu pada hasil pengisian soal pretest dan post-test pada kegiatan pelatihan demonstrasi penggunaan mesin produksi yang meliputi indikator : 1) Pemahaman prosedur kerja, 2) Pemahaman langkah pengoperasian mesin, 3) Pemahaman penggunaan variasi bahan rajang dan variasi ketebalan rajang, 4) Pemahaman sistem safety, 5) Pemahaman prosedur bilas cuci mesin setelah digunakan, 6) Pemahaman maintenece mesin, 7) Pemahaman cara penyimpanan mesin.

Berdasarkan ketujuh indikator yang terdapat dalam soal pre-test dan post-test, didapatkan nilai rata-rata soal pre-teset sebesar $40 \%$, sedangkan hasil nilai rata-rata dari jawaban soal post-test sebesar 60\%. Hasil ini masih dibawah standar capaian program. Sehingga pentingnya suatu kerangka monitoring berupa pendampingan program yang berkelanjutan. Mengingat peserta yang dilatih merupakan para kaum penyandang disabilitas tuna grahita, sehingga efektifitas keterlibatan pihak pengasuh panti merupakan kunci utama dalam kegiatan pemberdayaan wirausahawan disabilitas. Pada langkah pemberdayaan kedepan, diharapkan adanya keterlibatan dari pihak yang berkompeten dalam bidang pengembangan model/metode pembelajaran khusus bagi kaum penyandang disabilitas guna meningkatkan hasil belajar yang konstruktif.

\section{DAFTAR PUSTAKA}

[1] "website daftar panti asuhan di Malang Raya", [Internet]. 2015 [cited 2017 Mei 23]; Available fro https://ngalam.co/2016/01/22/daftar- panti-asuhandi-malang-raya/.

[2] “website dinas sosial kota malang”, [Internet]. 2017 [cited 2017 Mei 23]; Available from: http://sosial.malangkota.go.id/informasi/.

[3] Peraturan Daerah Kota Malang "Peraturan Daerah Kota Malang No 2 Tahun 2014. Tentang Perlindungan dan Pemberdayaan Disabilitas". Kota Malang, 2014.

[4] Pranata, Kurriawan B. Ghufron, M. Sulistyanto, M.P. T. "Peningkatan Produksi dan Kualitas Produk Camilan Keripik Ketela di Kec. Trawas, Kab. Mojokerto" Journal of Innovation And Applied Technology : Vol 4, No 1 : 171-559-1-SM, 2018.

[5] Garside, Annisa Kesy \& Sudjatmiko. "Rancang Bangun Mesin Pengiris Tempe Multi Fungsi Pada UKM-SANAN Malang” : Seminar Nasional dan Gelar Produk (SENASPRO), 2016.

[6] Sulistyanto, M. P. T. Pranata, Kurriawan B. Solikhan. Ghufron, M. "Pemberdayaan Kelompok Petani Jamur Tiram Desa Duyung Kecamatan Trawas Kabupaten Mojokerto" MARTABE: Jurnal Pengabdian Masyarakat : Vol 1, No 3: 108-116, 2018.

[7] Ihwah, Azimatul. Setiyawan, Danang. T. "IbM UKM Kerupuk Ikan di Desa Pangkah Wetan Kecamatan Ujung Pangkah Kabupaten Gresik Jawa Timur" : Jurnal Akses Pengabdian Indonesia Vol 3 No 1:1-6, 2018.

\section{PENGHARGAAN}

Kami ucapan terima kasih kepada Kemenristekdikti yang telah memberikan pendanaan pengabdian tahun pelaksanaan tahun 2018, LPPM Universitas Kanjuruhan 
Malang yang membantu terlaksana dan terwujudnya pengabdian ini, dan kepada Yayasan Panti asuhan Bakti Luhur yang telah bersedia menjadi Mitra dan membantu pengabdian tahun 2018 ini. Semoga kegiatan pengabdian ini dapat bermanfaat dan dapat lebih mengembangkan potensi keripik tempe kedepannya. 